risk ratio of between 1.6 and $2 \cdot 5$ in cigarette smokers. ${ }^{1}$ In a Copenhagen study of 3772 smokers and 1440 non-smokers, however, the risk of fatal and non-fatal myocardial infarction combined was excessive for smokers and was no different for smokers of pipes, cigars, and cigarettes, with heavy smokers of cheroots at greatest risk. ${ }^{7}$ Auerbach and Garfinkel, in a necropsy study of 1412 men, found an increase in the extent and complexity of aortic atherosclerotic plaques in pipe and cigar smokers as well as cigarette smokers. ${ }^{8}$ In other reports no association could be found between pipe and cigar smoking and stroke ${ }^{9}$ or peripheral vascular disease. ${ }^{10}$ Little has been published about the influence of cigar and pipe smoking on mortality after myocardial infarction. Hickey et al found an increase in subsequent mortality of similar proportions in survivors who continued to smoke cigarettes and in those who smoked cigars but no increased mortality in pipe smokers. ${ }^{11}$

Several studies have shown that carboxyhaemoglobin concentrations and other markers of inhalation are raised in cigarette smokers who change to pipe or cigar smoking. ${ }^{12-15}$ So the smoking of pipe or cigar tobacco by ex-cigarette smokers after myocardial infarction probably increases their risk of further coronary episodes, though more secondary prevention studies are required to confirm this view.

What advice, then, should be given to cigarette smokers with overt coronary heart disease? Can they safely change to pipes or cigars? Evidence from primary and secondary prevention studies of coronary heart disease that cigar and pipe tobacco are independent risk factors is conflicting and is flimsy compared with the evidence on cigarette smoking. Nevertheless, complete abstention from tobacco is probably sound advice, at least in cigarette smokers and in those with overt coronary heart disease. Apart from suffering possible deleterious effects, survivors of myocardial infarction who continue to smoke a pipe or cigars, or who change to these forms of smoking, show a peristent dependency-which in my own clinical experience indicates less than satisfactory motivation and therefore a greater likelihood of recidivism. In encouraging cigarette smokers to stop the greatest effect is achieved by careful counselling by a dedicated and informed health professional. Full knowledge of the harmful effects of smoking and of the benefits of giving up, if adequately conveyed to the patient who is anxious to quit the habit, will frequently succeed in making him stop smoking completely. Recourse to alternatives, such as pipe or cigar smoking or nicotine chewing gum, must be regarded as second best.

\section{RISTEARD MULCAHY}

Professor of Preventive Cardiology,

St Vincent's Hospital, University College,

Dublin 4

1 Surgeon General. The health consequences of smoking. Cardiovascular disease. A report of the Surgeon General. Rockville, Maryland: US Department of Health and Human Services, Public Health Service, 1983.

2 Doll R, Peto R. Mortality in relation to smoking: 20 years' observations on male British doctors. BrMed f 1976;ii: 1525-36.

3 Enstrom JE. Trends in mortality among California physicians atter giving up smoking: 1950-79. BrMed f 1983;286:1101-5.

4 Mulcahy $R$. Influence of cigarette smoking on morbidity and mortality after myocardial infarction. Br Heart $\mathcal{F}$ 1983;49:410-5.

5 Jarvis $M$, West $R$, Tunstall-Pedoe $H$, Vesey $C$. An evaluation of the intervention against smoking in the Multiple Risk Factor Intervention Trial. Prev Med (in press)

6 Multiple Risk Factor Intervention Trial Research Group. Multiple Risk Factor Intervention Trial: risk factor changes and mortality results. $\mathcal{J} A M A$ 1982;248:1465-77.

7 Gyntelberg F, Lauridsen L, Pedersen PB, Schubell K. Smoking and risk of myocardial infarction in Copenhagen men aged 40-59 with special reference to cheroot smoking. Lancet 1981;i:987-9.

8 Auerbach $\mathrm{O}$, Garfinkel $\mathrm{L}$. Atherosclerosis and aneurysm of the aorta in relation to smoking habits and age. Chest 1980;78:805-9.

9 Rogot E, Murray JL. Smoking and causes of death among US veterans: sixteen years of observation. Public Health Rep 1980;95:213-22.

10 Feinleib M, Williams RR. Relative risks of myocardial infarction, cardiovascular disease and peripheral vascular disease by type of smoking. In: Wynder EL, Hoffman D, Gori GB, eds. Modifying the risk for the smoker. Vol 1. Proceedings of the third world conference on smoking and health, New York 1975. Washington: US Department of Health, Education, and Welfare, 1976:243-56. (DHEW Publication No (NIH) 76-1221.)
11 Hickey N, Mulcahy R, Daly L, Graham I, O'Donoghue S, Kennedy C. Cigar and pipe smoking elated to four year survival of coronary patients. Br Heart $\mathcal{A} 1983 ; 49: 423-6$.

12 Castleden CM, Cole PZ. Inhalation of tobacco smoke by pipe and cigar smokers. Lance $1973 ; i: 21-4$.

13 Goldman AL. Carboxyhemoglobin levels in primary and secondary cigar and pipe smokers. Chest 1977;72:33-5.

14 Turner JAM, Sillett RW, McNichol MW. Effect of cigar smoking on carboxyhaemoglobin and plasma nicotine concentrations in primary pipe and cigar smokers and ex-cigarette smokers. $\mathrm{Br}$ Med f 1977;ii:1387-9.

15 Ronan G, Ruane P, Graham IM, Hickey N, Mulcahy R. The reliability of smoking history amongst survivors of myocardial infarction. Br f Addict 1981; 76:425-8.

\section{Scots lead the way on alcohol}

After a four year gestation the Scottish Health Education Coordinating Committee has produced the most impressive plan of action yet seen in Britain on how to combat alcohol problems. ${ }^{1}$ The report recognises that this is a job not just for government or for doctors (as some politicians have suggested ${ }^{2}$ ) or any other single group but a job for everybody in Scotland. When they read this report politicians, doctors, civil servants, teachers, policemen, union leaders, broadcasters, and many other groups will all find that they have been allotted a role in reducing Scotland's alcohol problems.

The past 10 years have seen a plethora of reports on alcohol, but most have been concerned with describing the problems associated with alcohol rather than a plan for overcoming them..$^{3-10}$ The only report that came close to matching this present Scottish report in the scope of its suggestions was the suppressed report by the government's think tank (Central Policy Review Staff $).{ }^{6}$ The flimsy Department of Health and Social Security document Prevention and Health: Drinking Sensibly, which could be seen as the government substitute for the suppressed report, was much stronger on platitudes than suggestions. ${ }^{8}$

In 1980 the Scottish Health Service Planning Council gave high priority to prevention in its report Scottish Health Authorities' Priorities for the Eighties, and it rated preventing alcohol abuse as second only to preventing smoking related diseases." The Scottish Health Education Coordinating Committee adopted similar priorities and set up a core group under the chairmanship of Sir John Crofton to produce this plan of action. The plan was originally intended to be for health boards, local authorities, and voluntary bodies, but the committee was wise enough to expand the plan to cover other national groups. The boldness in expanding the remit of the committee and the forcefulness, clarity, and comprehensiveness of its conclusions are all, we suspect, attributable in large part to the work of Sir John, who is well known for his excellence in chairing committees.

The report begins with an outstanding review of how the Scots (and sometimes all of the British) drink and the problems they experience as a result. The often quoted statistic that alcohol consumption in Britain almost doubled between 1950 and 1980 is brought up to date with data that show that it fell between 1980 and 1982 and rose again only slightly in 1983. Pie diagrams illustrating what we drink show how the "wine slice" is increasing and the "beer slice" decreasing, although the latter still accounts for more than half of consumption. A very recent paper from the professor of psychiatry in Edinburgh shows that the $11 \%$ fall in consumption between 1979 and 1982 was followed by a $19 \%$ fall in first admissions for alcohol dependence, a $16 \%$ fall in drunkenness convictions, a $7 \%$ fall in drinking and driving convictions, and a $4 \%$ fall in deaths from cirrhosis. ${ }^{12}$

Problems associated with alcohol are then categorised in 
the report into medical, social, and those related to the law, and further categorised into those associated with intoxication (for example, alcoholic poisoning, head injury, drug overdose, domestic violence, child neglect and abuse, absenteeism, road traffic accidents, drinking and driving, homicide) excessive use (fatty liver, cardiomyopathy, memory impairment, cancers of the mouth, throat, and gullet, financial difficulties, divorce, homelessness, habitual convictions for drunkenness), and dependency (anxiety, epilepsy, delirium tremens, personality change, fraud). Wherever possible numbers are put on these associations, and this categorisation is very effective in bringing home the tremendous breadth and depth of problems associated with alcohol-and the report does not confuse causation and association. The report puts the total cost to Britain of alcohol misuse conservatively at $£ 1000 \mathrm{~m}$; a study published in the March issue of the British Fournal of Addiction suggests an even higher figure of $£ 1500 \mathrm{~m}$ (1983 prices). ${ }^{13}$

This important but brief chapter should drive the report's readers on to their own chapters anxious to see what they can do to help-for there are then detailed recommendations for each group. The longest section is that devoted to the National Health Service, but the other sections address the government, the Scottish Office, the Scottish Home and Health Department, the Scottish Education Department, the health boards, the local authorities, the educational services, the Health and Safety Executive, voluntary bodies, trade unions, employers' associations, the media, and the courts. The recommendations addressed to the NHS include a six part policy for the use of alcohol on NHS premises, and an impression of the detail of the report can be gained by noting that there are nine specific recommendations for senior hospital medical staff, seven for the professional bodies of general practitioners as well as four for the primary health care team, and 12 for area health education officers.

But perhaps the one group that needs to read this report more closely than any other are the members of the Department of Health and Social Security in London, for surely England deserves such a report. The excuse that Scotland's alcohol problems are appreciably worse than those south of the border is no longer valid,,$^{14}$ and to bleat that these exercises are easier in small countries would be to admit defeat even before starting. England, Wales, and Northern Ireland should all have reports as impressive as this one from Scotland, and what all need even more is action along the lines suggested in the Scottish report.

1 Scottish Health Education Coordinating Committee. Health education in the prevention of alcohol related problems. Edinburgh: Scottish Home and Health Department, 1985. (Copies ar available from the Scottish Health Education Coordinating Committee, St Andrew's House, Edinburgh EH1 3DE 0315568501 ext 2438

Veitch A. Minister clashes with BMA on alcohol. Guardian 1984 November $29 \cdot 4$

Special Committee of the Royal College of Psychiatrists. Alcohol and alcoholism. London: Tavistock Publications 1979 .

World Health Organisation Expert Committee. Problems related to alcohol consumption. Geneva: WHO, 1979 .

5 House of Commons Expenditure Committee. Report on preventive medicine, London: HMSO, 1977.

6 Bruun K. Alcohol policies in the United Kingdom. Stockholm: Sociologiska Institutionen, 1982.

Department of Health and Social Security Advisory Committee on Alcoholism. Kiport on prevention. London: HMSO, 1978

8 Department of Health and Social Security. Prevention and health: drinking sensibly. London: HMSO, 1981.

9 Robertson I, Hodgson R, Orford J, McKechnie R. Psychology and problem drinking. Report of a working party convened by the British Psychological Society division of clinical psychology. Leicester: BPS, 1984

10 Anonymous. Drink. Which? 1984 ; October:445-9.

11 Scottish Health Services Planning Council. Scottish health authorities' priorities for the eighties. Edinburgh: Scottish Home and Health Department, 1980.

12 Kendell RE. The beneficial consequences of the United Kingdom's declining per capita consumption of alcohol in 1979-82. Alcohol and Atcoholism 1984;19:271-6.

13 McDonnell R, Maynard A. The costs of alcohol misuse. Brf Addict 1985;80:27-35.

14 Latcham RW, Kreitman N, Plant MA, Crawford A. Regional variations in British alcoho morbidity rates: a myth uncovered? I Clinical surveys. Br Med $\mathcal{f}$ 1984;289:1341-3.

15 Crawford A, Plant MA, Kreitman N, Latcham RW. Regional variations in British alcohol morbidity rates: a myth uncovered? II Population surveys. Br Med $\mathcal{f}$ 1984;289:1343-5.

\section{Family practitioner committees: a price for independence?}

The conflict between the government and the profession over the limited list has overshadowed an important change in the organisation of the NHS. On 1 April family practitioner committees in England and Wales become autonomous authorities, independent of district health authorities and directly accountable to the Department of Health and Social Security. The aims of this independence, as seen by the government, are: to improve primary care; to strengthen the planning of local health care (in concert with district health authorities) and the collaboration between family practitioner committees and other services provided by local government; to improve the committees' administrative efficiency; and to make them more accountable to the DHSS. Above all the government is seeking greater value for money from the primary care sector. It will use the new arrangements for family practitioner committee accountability to achieve this. But as might be expected nowadays the new committees will receive no extra funds from the DHSS with which to discharge their wider responsibilities in planning, etc.

Independence was achieved only after a long struggle by the profession against considerable odds. The Society of Family Practitioner Committees and the BMA's General Medical Services Committee were almost alone in pressing for legislation to implement this change. The governmenttogether with many other powerful bodies, including the other political parties-were not convinced that family practitioner committees should be hived off from the district health authorities. There were doubts about whether independence would undermine cooperation at the local level between family practitioner committees and district health authorities and whether autonomous family practitioner committees would exercise sufficient "control" over the contractor professions-general practitioners, dentists, pharmacists, and opticians. Those who favoured independence saw the new status as a vital catalyst for change; the standing of primary care within the NHS would be enhanced by putting it on an equal administrative footing with the hospital sector. Any changes, however, must not prejudice the committees' duties on "pay, rations, and discipline," which have been an essential responsibility in the running of the primary care service.

Since the idea of independence was originally mooted other-largely unforeseen-developments have occurred that will undoubtedly affect the style of the new autonomous family practitioner committees. It is already apparent that family practitioner committees are acquiring new executive teeth. Doctors have already seen their influence wane in the forum of the Society of Family Practitioner Committees. A new generation of family practitioner committee chairmen and lay and professional members have been hand picked by ministers. Indeed, ministers have insisted on personally selecting from the nominees of local medical committees those doctors who fill the professional seats on the family practitioner committees, and in some areas local medical committee chairmen and secretaries have not been reappointed, a loss of experience the committees can ill afford.

Undoubtedly family practitioner committees across the country will appear to be "under new management," and this signals the end of what some outsiders saw as a too cosy relationship. The influence of the profession may be weakened 